\title{
Особливості програми фізичної терапії осіб з невропатією лицевого нерва у відновлювальному періоді
}

\author{
УДК: 796.015:616.833-002
}

\author{
І. О. Жарова, О. Ю. Пашов, О. В. Бісмак
}

Національний університет фізичного виховання і спорту України, Київ, Україна

\begin{abstract}
Резюме. Мета. Охарактеризувати програму фізичної терапії осіб з невропатією лицевого нерва у відновлювальний період. Матеріал і методи. У дослідженні брали участь 60 пацієнтів з невропатією лицевого нерва, які були розподілені на дві групи: основну (31 особа) та контрольну (29 осіб). У процесі дослідження використано методи аналізу, синтезу та узагальнення даних науково-методичної літератури, контент-аналіз медичних карт хворих, реабілітаційне обстеження. Результати. На підставі реабілітаційного обстеження розроблено програму фізичної терапії, основною особливістю якої було використання методологічного підходу МКФ, направленого на відновлення не лише структури і функції, але й на підвищення рівня фізичної та соціальної активності пацієнтів з невропатією лицевого нерва. На рівні структури і функції використовували такі засоби фізичної терапії, як кінезитерапія (терапевтичні вправи для м'язів обличчя перед дзеркалом, дихальні вправи), нейром'язове перенавчання, масаж, самомасаж, тейпування, рефлексотерапія; на рівні діяльності та участі такі, як кінезитерапія з нейром'язовою активацією (терапевтичні вправи для мімічних та жувальних м'язів перед дзеркалом), дзеркальна терапія із симуляцією виразів різноманітних емоцій відповідно до соціального контексту, звукова гімнастика. На рівні структури і функції за МКФ для нормалізації м'язового тонусу і профілактики розвитку синкінезій основну увагу приділяли нейром'язовому перенавчанню з біологічно зворотним зв'язком. Як біологічний зворотний зв'язок використовували візуальний контроль - дзеркало. На рівні діяльності та участі дзеркальна терапія була направлена на відновлення та покращення мовлення та комунікації пацієнтів. Висновки. Розроблена програма будувалася з урахуванням поліморфізму симптоматики і широкого арсеналу засобів фізичної терапії. Основний фокус застосування реабілітаційних засобів у відновлювальний період - боротьба з контрактурами та синкінезіями на ураженому боці та відновлення мовлення, харчування та спілкування, що сприяє покращенню якості життя пацієнтів з даною патологією.
\end{abstract}

Ключові слова: невропатія, лицевий нерв, фізична терапія, реабілітація, кінезотерапія, пацієнт.

Features of physical therapy program for persons with facial nerve neuropathy during the recovery period

\section{O. Zharova, O. I. Pashov, O. V. Bismak}

National University of Physical Education and Sport of Ukraine, Kyiv, Ukraine

Abstract. Objective. The aim is to characterize the program of physical therapy for persons with facial nerve neuropathy in the recovery period. Materials and methods. The study involved 60 patients with neuropathy of the facial nerve, who were divided into 2 groups: the main group (31 people) and the control group (29 people). In the course of the study, methods of analysis, synthesis and generalization of scientific and methodological literature data, content analysis of medical records of patients, and rehabilitation examination were used. Results. Based on the rehabilitation examination, a physical therapy program was developed, the main feature of which was the use of the ICF methodological approach, aimed at restoring not only structure and function, but also increasing the level of physical and social activity of patients with facial nerve neuropathy. At the level of structure and function, we used the following means of physical therapy: kinesiotherapy (therapeutic exercises for the muscles of the face in front of a mirror, breathing exercises), 
neuromuscular retraining, massage, self-massage, taping, reflexology. At the level of activity and participation: kinesiotherapy with neuromuscular activation (therapeutic exercises for mimic and masticatory muscles in front of a mirror), mirror therapy with simulated expressions of various emotions in accordance with the social context, sound gymnastics. It is noted that at the level of structure and function according to ICF, for the normalization of muscle tone and prevention of the development of synkinesis, the focus was on neuromuscular retraining with biofeedback. A visual control - a mirror - was used as a biological feedback. At the activity and participatory level, mirror therapy was aimed at recovering and improving patients' speech and communication. Conclusions. The developed program was built with account for the polymorphism of symptoms and a wide range of physical therapy tools. The main focus of the use of rehabilitation means in the recovery period is the fight against contractures and synkinesis on the affected side and the restoration of speech, nutrition and communication, which helps to improve the quality of life of patients with this pathology. Keywords: neuropathy, facial nerve, physical therapy, rehabilitation, kinesiotherapy, patient.

Постанова проблеми. Аналіз останніх досліджень і публікацій. Невропатія лицевого нерва $\epsilon$ поширеним захворюванням нервової системи. Медична статистика стверджує, що захворювання і пошкодження лицевого нерва посідають друге місце серед патології перифреричної нервової системи (захворюваність коливається в межах від 8 до 240 хворих на 100 тис. населення) та перше місце серед уражень черепно-мозкових нервів [1, 7].

За даними різних авторів, невропатія лицевого нерва зустрічається однаково часто як у чоловіків, так і у жінок $[8,13]$. Ідіопатичні невропатії спостерігаються у $75 \%$ хворих, отогенні у $15 \%$, іншої етіології - у $10 \%$ хворих [8]. У кожного третього хворого ураження лицевого нерва призводить до розвитку таких ускладнень, як контрактура мімічних м'язів (25-30 \% випадків [5]) і патологічні синкинезії, а у кожного сьомого хворого, що одужав, згодом спостерігається рецидив захворювання [1].

Як свідчать літературні джерела, невропатія лицевого нерва спричинює незворотні процеси у тканинах нерва, часто не підлягає відновленню, що обумовлює трофрічні порушення м'язів обличчя [7]. Навіть після лікування та реабілітації у $10-25 \%$ випадків відмічають неповне відновлення фуннкції мімічних м'язів, у $18 \%$ випадків залишається виражений косметичний дефект, а в 16-32\% випадків формується постпаретична контрактура [13]. Зазначене підкреслює важливість і необхідність включення фізичної терапії у комплексну реабілітацію пацієнтів з невропатією лицевого нерва $[6,10]$.

Аналіз наукової літератури з проблематики застосування засобів фрізичної терапії при невропатії лицевого нерва виявив обмежену кількість публікацій, тому питання розробки нових програм фрізичної терапії пацієнтів з невропатії лицевого нерва, незважаючи на багаторічні дослідження ряду наукових шкіл, залишається актуальним.
Мета дослідження - охарактеризувати програму фрізичної терапії осіб з невропатією лицевого нерва у відновлювальному періоді.

Матеріали і методи дослідження. Проведено контент-аналіз 60 історій хвороб пацієнтів з невропатіями лицевого нерва, які були розподілені на дві групи: основну (31 особа) та контрольну (29 осіб). У процесі дослідження використано методи аналізу, синтезу та узагальнення даних науково-методичної літератури та Інтернет джерел, контент-аналіз медичних карт хворих, реабілітаційне обстеження. Дослідження проводилося на базі Crystal Touch Bell's Palsy clinic, Rotterdam, The Netherlands (2017-2019 pp.).

Результати дослідження. Відомо, що невропатія лицевого нерва, або параліч Белла, запальне ураження нерва, що іннервує мімічні м'язи однієї половини обличчя $[1,7]$. В результаті в м'язах обличчя розвивається слабкість, що призводить до зниження (парез) або повної відсутності (параліч) мімічних рухів і появи асиметрії обличчя. Крім того, у пацієнтів спостерігається: згладжування шкірних складок на ураженому боці обличчя; здуття щоки (симптом вітрила) при видиху і розмові в момент вимови приголосних букв; в разі примружування око на боці ураження не закривається, а очне яблуко повертається вгору і злегка назовні (симптом Белла); тверда їжа під час жування потрапляє між яснами і щокою, а рідка виливається через край рота ураженої сторони; порушення мови.

За даними А. С. Артюшкевич зі співавт., параліч мімічних м'язів призводить не тільки до косметичних вад і обтяжливих переживань пацієнта, а й до порушення фрункцій ковтання і жування, а також до фронації [1]. Нейропаралітичний кератит, причиною якого у пацієнтів з ураженням лицевого нерва слугують лагофттальм і порушення сльозовиділення, призводить до рубцювання рогівки, зниження і втрати зору. Крім того, у пізній відновлювальний період пацієнтів продовжують турбувати синкінезії м'язів обличчя та постпара- 
літична контрактура [13]. Таким чином, ураження лицевого нерва значно знижує якість життя пацієнтів.

У сучасній медицині все більшого впливу набуває модель здоров'я і хвороби, центром якої $€$ пацієнт як особистість зі своїми переживаннями і побоюваннями, прагненнями і сподіваннями. Традиційний біомедичний підхід призводить до того, що фрахівці звертають увагу тільки на клініко-лабораторні та інструментальні показники, залишаючи без уваги психосоціальні аспекти хвороби. Однак для людини важливо те, якою мірою захворювання впливає на її фрізичний, емоційний і соціальний добробут, тобто на якість життя [3].

Наразі актуальним питанням $€$ розробка есрективної програми реабілітації пацієнтів 3 невропатіями верхньої кінцівки, яка включає комплексний багатоаспектний, індивідуалізований підхід, обгрунтований сучасною спрямованістю медицини, зокрема впровадженням Міжнародної класифрікації функціонування, обмеження життєдіяльності та здоров'я (МКФ) в практику роботи фахівців системи охорони здоров'я. За допомогою МКФ є можливість точно відобразити стан здоров'я пацієнтів з різним ступенем порушення функціонування. Домени МКФ характеризують функції та структури організму, діяльності та участі, а також фрактори навколишнього середовища, що впливають на здоров'я і життєдіяльність пацієнтів.

На думку Т. В. Буйлова, застосування МКФ у практичній діяльності дозволяє: провести всебічний аналіз наявних обмежень життєдіяльності; змінити рівень і вектор побудови програм реабілітації; уточнити послідовність реабілітаційних заходів; провести аналіз фракторів контексту (особистісних і зовнішнього середовища); оцінити ефрективність проведеної реабілітації [3].

Основними реабілітаційними заходами під час побудови комплексної програми відновлення є:

1) обстеження, оцінка, визначення потреб пацієнта;

2) визначення цілей та плану заходів з фрізичної терапії;

3) впровадження програми втручання;

4) визначення результатів втручання;

5) надання рекомендацій пацієнтам.

Виходячи 3 вищезазначеного, було проведено реабілітаційне обстеження пацієнтів 3 невропатіями лицевого нерва, яке включало: опитування, огляд, збір анамнезу, визначення ступеня неврологічного дефріциту, наявності рухових i чутливих порушень, м'язових гіпотрофій та атрофій, контрактур суглобів та м'язів, застосовувалися діагностичні шкали.
Опитування включало в себе скарги пацієнта, як основні, так і додаткові, уточнювався час прояву симптоматики, що дає змогу проаналізувати швидкість прогресування невропатії, кількість рецидивів за рік. Було зібрано анамнез перенесених супутніх захворювань та попередніх хірургічних втручань. Пальпаторно визначали наявність болючості, гіпертрофічно змінених тканин. Опитування дозволило з'ясувати першочергові завдання реабілітаційних втручань та потреби пацієнта.

Під час огляду пацієнт виконував рухи лицевими м'язами: заплющити очі (спочатку обидва, потім по черзі), підняти, потім нахмурити брови, надути щоки, зморщити ніс, показати зуби, насупитися, посміхнутися тощо. При цьому звертали увагу на симетричність та правильність виконання тестових рухів з правого та лівого боку обличчя.

На основі контент-аналізу медичних карток та реабілітаційного обстеження ми розробили програму фрізичної терапії для пацієнтів основної групи, особливістю якої було використання методологічних підходів та доменів МКФ. У контрольній групі застосовували традиційні засоби фрізичної терапії, які використовуються у лікувальних закладах (терапевтичні вправи для м'язів обличчя, масаж, процедури апаратної фрізіотерапії).

Під час розроблення програми фрізичної терапії важливе значення має встановлення та фрормулювання цілей реабілітаційного втручання. У фрізичній реабілітації/терапії цілі поділяють на короткотривалі та довготривалі. Останні потребують понад три тижні для досягнення. Для коректної постановки цілей у різних сорерах діяльності i, зокрема, фрізичній терапії, науковці та практики рекомендують застосовувати SMART форомат [4].

Довгостроковими цілями на рівні структури та фрункції (відповідно до МКФ) були:

- відновлення порушеної фрункції мімічних м'язів;

- зменшення больового синдрому;

- профрілактику контрактур.

Довгостроковими цілями на рівні діяльності та участі (відповідно до МКФ) були:

- відновлення правильної мови;

- подолання проблем із харчуванням;

- покращення спілкування - як вербального, так і невербального.

На рівні структури та фрункції використовували такі засоби фрізичної терапії: кінезитерапію (терапевтичні вправи для м'язів обличчя перед дзеркалом, дихальні вправи), нейром'язове перенавчання, масаж, самомасаж, тейпування, рефлексотерапію. 
На рівні діяльності та участі для відновлення рухливості мімічних м'язів з ураженого боку обличчя застосовували кінезитерапію 3 нейром'язовою активацією (терапевтичні вправи для мімічних та жувальних м'язів перед дзеркалом), дзеркальну терапію зі симуляцією виразів різноманітних емоцій відповідно до соціального контексту, звукову гімнастику (рис. 1).

Основним засобом кінезитерапії були терапевтичні вправи, які включали спеціальні рухи для мімічних і жувальних м'язів. Мімічну гімнастика та вправи для жувальних м'язів проводили щодня. Тривалість занять терапевтичними вправами у відновлювальний період 25-40 хв з паузами відпочинку у разі стомлення. Пацієнтам рекомендували самостійні заняття 2-3 рази на день. Заняття проводили в індивідуальному порядку.

Нейром'язове перенавчання застосовували 3 метою нормалізації м'язового тонусу і профрілактика розвитку синкінезій. Пацієнту пояснювали анатомію м'язів, механізми їх роботи, розповідали, що неусвідомлені рухи піддаються усвідомленому контролю за допомогою біологічного зворотного зв'язку - проприоцептивного, сенсорного, візуального. Як біологічний зворотний зв'язок використовували візуальний контроль дзеркало. Нейром'язове перенавчання сприяло також формуванню більш точних рухових патернів [14].

Велику увагу приділяли навчанню розслаблення і дозованого напруження мускулатури здорової половини обличчя. Пацієнта просили довільно виділити чотири або п'ять градацій сили, наприклад, спочатку зімкнути очну щілину або розтягнути кут рота в «усмішці» 3 максимальною силою, потім у півсили, у чверть сили, в одну восьму сили тощо. Хворий навчався напружувати неуражені м'язові групи, що забезпечують посмішку, сміх, увагу, плач, сум, а також артикуляцію деяких губних звуків («п», «б», «м», «в», «фр», «у», «о») із зусиллям, адекватним можливостям паретичних м'язів; при цьому м'язи здорової половини обличчя ніби підлаштовуються під паретичні м'язи протилежної сторони.

Для релаксації зовнішніх крилопіднебінних м'язів пацієнт зміщує на вдиху нижню щелепу в уражену сторону проти опору власної руки, на видиху щелепа пасивно зміщується в протилежну сторону. При двосторонній релаксації вказаних м'язів у першу фазу вправи щелепа активно висувається вперед на зразок ящика письмового столу і пасивно засувається назад у другу фразу.

Для посилення пропріоцепції паретичних м'язів обличчя перед заняттями терапевтичними вправами застосовували тейпування та масаж об-

\begin{tabular}{|c|c|}
\hline \multicolumn{2}{|c|}{$\begin{array}{c}\text { Програма фізичної терапії при невропатії лицьового нерва } \\
\text { у відновлювальний період }\end{array}$} \\
\hline$\nabla$ & $\nabla$ \\
\hline На рівні структури і фрункції & На рівні діяльності та участі \\
\hline$\nabla$ & $\nabla$ \\
\hline $\begin{array}{l}\text { Цілі: } \\
\text { • відновлення порушеної } \\
\text { функції мімічних м'язів } \\
\text { • профрілактика контрактур та } \\
\text { синкінезій }\end{array}$ & $\begin{array}{l}\text { Цілі: } \\
\text { • відновлення правильного } \\
\text { мовлення } \\
\text { • подолання проблем із } \\
\text { харчуванням, спілкуван- } \\
\text { ням }\end{array}$ \\
\hline$\nabla$ & $\nabla$ \\
\hline $\begin{array}{l}\text { Засоби фізичної терапії: } \\
\text { • терапевтичні вправи для } \\
\text { мімічних та жувальних } \\
\text { м'язів } \\
\text { • нейром'язове перенавчання } \\
\text { - масаж, тейпування } \\
\text { • ректростимуляція } \\
\text { рефлексотерапія }\end{array}$ & $\begin{array}{l}\text { Засоби фрізичної терапії: } \\
\text { • спеціальна артикулярна } \\
\text { гімнастика } \\
\text { • терапевтичні вправи для } \\
\text { мімічних та жувальних } \\
\text { м'язів } \\
\text { • дзеркальна терапія } \\
\text { • звукова гімнастика }\end{array}$ \\
\hline
\end{tabular}

Рисунок 1 - Блок-схема реабілітаційних заходів при невропатії лицевого нерва за МКФ

личчя. На думку О. К. Баханович зі співавт., кінезіотейпи, піднімаючи шкіру, активізують природні фрізіологічні процеси: поліпшують кровообіг, стимулюють роботу лімфатичної системи, приводять м'язи в тонус, усувають запалення, знеболюють, коригують положення м'язів, зменшують очну щілину, знімають набряк, обмежують розвиток асиметрії носогубних складок і розвиток синкінезій [2]. Кінезіотейпи накладали на 8-24 год залежно від стану мімічних м'язів.

Велике значення при невропатії лицевого нерва має масаж мімічних м'язів з ураженого та здорового боку обличчя у ділянці чола, навколо очниць, губ, щік, шиї: погладжування, розтирання, натискання, безперервна вібрація і поплескування долонною поверхнею пальців [9]. При синкінезіях і контрактурі застосовували масаж 3 розминанням локальних м'язових вузликів, методи постізометричної релаксації. У заключній частині процедури проводили погладжування всіх ділянок обличчя. Масаж проводили щодня 30-40 хв.

Для нормалізації психоемоційного стану та тонізуючого впливу на організм пацієнти виконували статичні і динамічні дихальні вправи в різних варіантах; вправи ізотонічного та ізометричного характеру.

Із засобів апаратної фрізіотерапії використовували електростимуляцію м'язів обличчя. Електростимуляцію нерва проводили по рухових точках синусоїдальним струмом у вихідному положенні лежачи [15]. Тривалість процедури 15-20 хв, через день. На курс лікування 15-20 процедур. 
Як свідчать літературні джерела, висока терапевтична ефрективність рефлексотерапії при невропатії лицевого нерва насамперед обумовлена іï позитивним впливом на основні патогенетичні механізми захворювання (розлад мікроциркуляції, ішемія, гіпоксія нерва, порушення тканинного метаболізму, набряк), а також наявністю інших лікувальних ефектів - міорелаксуючого, міотонізуючого, аналгетичного, седативного та імуномодулюючого [11, 12]. Вплив починали 3 дистальних точок загальної дії, потім на здоровому боці використовували місцеві точки залежно від уражених груп м'язів за седативною методикою. На ураженому боці застосовували тонізуючий вплив. У разі виникнення контрактур в ділянці обличчя використовували седативну дію з обох боків в ділянці м'язів, що знаходяться в гіпертонусі.

На рівні діяльності та участі крім гімнастики для мімічних м'язів, з перших же занять застосовували артикулярну та звукову гімнастику. Хворому пропонували: вимову звуків «о», «у», «б», «до», «в», «фр», «м» поєднувати з посиленим рухом губ; швидко вимовляти звукосполучення: «ой», «ок», «пт» та ін,; злито і по складах вимовляти слова 3 наголосом на «о», «у», «ю», «і», «и», «е», «е» 3 надмірним рухом губ вперед і в бік (наприклад: го-род, о-ло-во, зо-ло-то, доло-то, кос-мос, но-чі, по-ні, ко-ні, ки-мо-но, домі-но, ук-роп; ку-ку-ру-дза, фут-бол, фрут-ляр); розучувати вірші з читанням їх перед дзеркалом у повільному темпі з підкресленою артикуляцією губами на кожному складі; вимовляти окремі букви, склади, слова і скоромовки тільки хворим боком обличчя, притримуючи рукою здорову сторону. Заняття проводили щодня 35-40 хв.

\section{Література}

1. Артюшкевич АС, Руман ГМ, Адащик НФ, Байда АГ. Клиника, дигностика и лечение невропатий лицевого нерва [Clinical picture, diagnosis and treatment of neuropathies of the facial nerve]. Современная стоматология. 2015;(2):23-8.

2. Баханович ОК, Лайко ТЮ, Тарасова ЕИ. Применение метода кинезиотейпирования в комплексной реабилитации пациентов с заболеваниями костно-мышечной системы [Application of the kinesio taping method in the complex rehabilitation of patients with diseases of the musculoskeletal system]. Медицинские новости. 2016;8:39-40.

3. Буйлова ТВ. Международная классификация функционирования как ключ к пониманию философии реабилитации [International classification of functioning as a key to understanding the philosophy of rehabilitation]. MeдиАль. 2013;2(7):26-31.

4. Герцик АМ. Мета, цілі та завдання фізичної реабілітації: системний підхід [Purpose, goals and objectives of physical rehabilitation: a systematic approach]. Молодіжний науковий вісник Східноєвропейського національного університету імені Лесі Українки. 2015;20:121-6.

5. Іваницька ОС, Рибалов ОВ, Скікевич МГ. Комплексне обстеження хворих із хронічними периферійними ураженнями лицевого нерва як основа підвищення ефективності їх лікування [Comprehensive examination
Ще однією особливістю програми фрізичної терапії, яка застосовувалася у пацієнтів основної групи, було використання дзеркальної терапії із виконанням спеціальних вправ, які симулювали вираження різноманітних емоцій відповідно до соціального контексту. Пацієнт, перебуваючи перед дзеркалом, демонстрував різні емоції у поєднанні з проголошенням фрраз, що характеризують певний емоційний стан, контролюючи при цьому вираз обличчя (щодня 20-30 хв).

Висновки. Розроблена програма будувалася з урахуванням поліморфізму симптоматики і широкого арсеналу засобів фрізичної терапії. Основний фокус застосування реабілітаційних засобів у відновлювальний період - боротьба з контрактурами та синкінезіями на ураженому боці та відновлення мови, харчування та спілкування. Розроблена програма враховує методологічний підхід МКФ, сприяє відновленню не лише функції і структури, а й покращенню соціальної активності пацієнтів з невропатією лицевого нерва.

На рівні структури і функції ми використовували кінезитерапію (терапевтичні вправи для м'язів обличчя перед дзеркалом, дихальні вправи), нейром'язове перенавчання, масаж, самомасаж, тейпування, рефлексотерапію; на рівні діяльності та участі - кінезитерапію з нейром'язовою активацією (терапевтичні вправи для мімічних та жувальних м'язів перед дзеркалом), дзеркальну терапію зі симуляцією виразів різноманітних емоцій відповідно до соціального контексту, звукову гімнастику.

Перспективи подальших досліджень. У перспективі планується визначення ефективності програми фізичної терапії для даної категорії пацієнтів.

of patients with chronic peripheral lesions of the facial nerve as a basis for improving the effectiveness of their treatment]. Актуальні проблеми сучасної медицини. Вісник Української медичної стоматологічної академії. 2012;4(36): 31-5.

6. Котешева ИА. Лечебная физкультура в терапии неврита лицевого нерва [Physiotherapy in the treatment of facial nerve neuritis]. Качество жиз ни. Медицина. 2004;4:71-5.

7. Кулакова ЛА, Славский АН, Трякина ЕГ. Клиника, диагностика и лечение поражений лицевого нерва в практике оториноларинголога [Clinic, diagnosis and treatment of lesions of the facial nerve in the practice of an otorhinolaryngologist]. Вестник оториноларингологии. 2009;(4):48-50.

8. Маркин СП. Поражения лицевого нерва в практике врача [Lesions of the facial nerve in the practice of a doctor]. Лечащий врач. 2013;(9):38-42.

9. Машенко ЯВ, Солопчук ДМ. Особливості використання засобів фізичної реабілітації при невриті лицьового нерву [Features of physical rehabilitation in case of neuritis of the facial nerve]. Збірник матеріалів наукових досліджень студентів та магістрантів Кам'янець-Подільського національного університету імені Івана Огієнка. 2011;3:88-93.

10. Петров КБ. Лечебная гимнастика при периферических нейропатиях лицевого нерва в остром периоде [Therapeutic gymnastics for peripheral 
neuropathies of the facial nerve in the acute period]. Лечебная физическая культура и массаж. 2007;(9):21-7.

11. Петров КБ. Физическая и кинезиологическая терапия при поражениях лицевого нерва: пособие для врачей [Physical and kinesiological therapy for lesions of the facial nerve: a guide for doctors]. Новокузнецк. 2000. $36 \mathrm{c}$.

12. Підлісний С. Фізична реабілітація при ураженні лицьового нерва [Physical rehabilitation for facial nerve damage]. Концепція розвитку галузі фрізичного виховання і спорту в Україні: збірник наукових праць. 2003;3(2): 70-4.

aniri2002@ukr.net
13. Рибалов ОВ. Сучасний погляд на виникнення та розвиток периферичних уражень лицевого нерва [Modern view on the origin and development of peripheral lesions of the facial nerve]. Актуальні проблеми сучасної медицини: вісник української медичної стоматологічної академії. 2014;4(48):286-90.

14. Ballet R. Facial Paralysis Rehabilitation: Re-Training selective muscle control. Int. Rehabil. 2012;4:67-74.

15. Vaffaa Kh. Electrostimulator in the treatment of a facial nerve lesion. Vrach. Delo. 2012;(4):87-9.

Надійшла 03.07.2020 